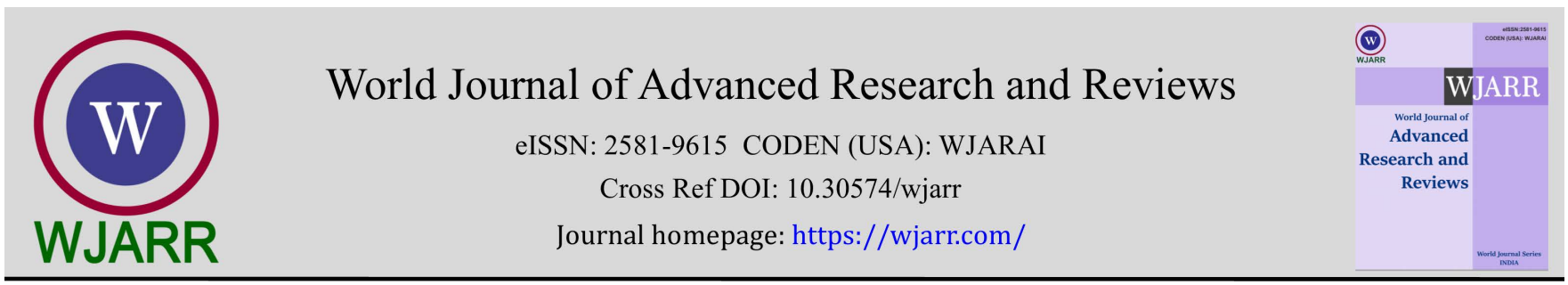

(RESEARCH ARTicle)

\title{
The effect of work motivation on employee performance: the case at OTUKSA Japan company
}

\author{
Dinh Van Thang 1,* and Nguyen Quoc Nghi ${ }^{2}$ \\ ${ }^{1}$ FPT Executive MBA Program, FPT University, Vietnam. \\ ${ }^{2}$ School of Economics, Can Tho University, Vietnam.
}

World Journal of Advanced Research and Reviews, 2022, 13(01), 404-412

Publication history: Received on 10 December 2021; revised on 12 January 2022; accepted on 14 January 2022

Article DOI: https://doi.org/10.30574/wjarr.2022.13.1.0047

\begin{abstract}
The study aims to evaluate the influence of work motivation on the work results of employees of Otuksa Japan. Research data were collected from a survey of 200 employees working at Otuksa Japan. Applying the structural equation modeling (SEM), the study has indicated factors positively affecting the work motivation of the employees include working conditions, income - benefits, career development, and workplace relationships. In which, career development puts the most impact on employee motivation. Most importantly, the study has shown a positive relationship between work motivation and the performance of Otuksa's employees.
\end{abstract}

Keywords: Work motivation; Performance; Employee; Otuksa Corporation Japan

\section{Problem statement}

Any company that has modern infrastructure and technology while does not have a dedicated workforce may bear a human resource with low efficiency. It is hard to compete with their enemies (Robbins and Judge, 2013). To effectively manage human resources, managers have to consider people as the central factor of the development and offer opportunities to promote the potentials of employees (Herzberg, 2005). This becomes possible if managers understand the desire of workers to give them the motivation to achieve the best results. Work motivation is one of the most important factors that strongly affect the performance of employees. Labor productivity is enhanced through motivational policies, this has been demonstrated in previous studies by Kamery (2004), Borman (2004), Mai Anh (2011). For employees to be motivated to work, managers need to build practical, timely, and appropriate policies for each individual to promote their work motivation.

Otuksa Japan Trading - Production - Import Export Production Trading Joint Stock Company (Otuksa Japan) specializes in agro-pharmaceuticals and seafood trading. More than $70 \%$ of the company's employees are sales staff. They are usually under lots of pressure such as sales pressure, pressure from customers, or the leader. If managers have appropriate policies to encourage employees, their work efficiency will improve. To evaluate the influence of work motivation on employees' work results, the study "Effect of work motivation on employee performance at Otuksa Japan" is necessary. Based on the obtained results, the study proposes some managerial implications to promote work motivation and improve results for employees at Otuksa Japan.

\footnotetext{
* Corresponding author: Dinh Van Thang

FPT Executive MBA Program, FPT University, Vietnam. 


\section{Theoretical framework and research model}

\subsection{Work motivation}

According to Herzberg (1959), work motivation is a psychological process arising from the excitement, direction, and perseverance of employees to achieve individual and organizational goals. Work motivation is the voluntary, desire, and effort to work that helps employees achieve personal goals, thereby obtaining the organizational objectives (Bedeian, 1993). Work motivation is an internal impulse based on an individual's basic conscious (or unconscious) needs that lead them to work towards the goals (Carr, 2005). As presented by Pinder (2014), work motivation is an assemblage of internal and external powerful energies of an individual to perform work-related behaviors and determine the direction, intensity, and duration of work.

\subsection{Work performance}

According to Judge and Bono (2001), work performance is measured by the evaluation of the leader, colleagues, and self-assessment. Kuvaas (2006) has stated that job performance is reflected by job completion (achievement of sales targets on time, difficult tasks that exceed expectations), relationship with customers (keep the existing customers and the ability to find potential ones), peer feedback, and the leader's feedback. According to Karunanithy and Ponnampalam (2013), job result is measured by the criteria of time principle, relationship with clients, relationship with colleagues, feedback from superiors, and self-confidence.

\subsection{Relationship between working conditions with motivation}

According to Kovach (1987), Anh (2017), a safe environment with reasonable working hours and a well-organized workplace may help promote employee motivation. In the organization, working conditions such as safety protective equipment make employees feel secure and focused on their work. This is the basis to create high productivity, quality, and work performance (Herzberg, 2003; Reio and Callahon, 2004; Robbins and Judge, 2014). Therefore, the study suggests hypothesis H1: Working conditions have a positive impact on the work motivation of employees at Otuksa Japan.

\subsection{Relationship between job characteristics and motivation}

Anh (2017) has argued that job characteristics show the way and the level of job performance. According to Kovach (1987), Hadi and Adil (2010), a job that always requires improvement is an important motivating factor for employees. If employees are proactive in performing work and the tasks are divided properly, they will be more confident and enthusiastic, thereby leading to higher motivation (Kamery, 2004). Thus, the study hypothesizes H2: Job characteristics positively affect the work motivation of employees at Otuksa Japan.

\subsection{The relationship between benefits and motivation}

Salary and bonus policies affect employee motivation (Thu and Khoi, 2014; Uyen, 2007). Studies by Osterloh et al. (2002), Herzberg (2003), Reio and Callahon (2004), Jankingthong and Rurkkhum (2012), Anh (2017) showed that salary, bonus, and welfare are factors that have the most impact on employee motivation. The study proposes hypothesis H3: Income and welfare have a positive impact on the work motivation of employees at Otuksa Japan.

\subsection{The relationship between career development and motivation}

Dung and Vy (2011) have indicated that training opportunities that satisfy the development needs of employees may stimulate them to perform better. In addition to this, Kovach (1987), Bretz et al. (1992) have said that career development is an essential goal of any worker which influences their work responsibilities. The promotion has a great impact on employee engagement, promoting greater dedication (Reio and Callahon, 2004; Robbins and Judge, 2014). Hence, hypothesis $\mathrm{H} 4$ is as follows: Career development has a positive impact on the work motivation of employees at Otuksa Japan.

\subsection{The relationship between corporate culture with motivation}

Corporate culture is one of the factors that directly affect employee motivation. According to Kovach (1987), Chew (2004), Shah et al. (2012), good corporate cultures increase the cooperation of the team which enhances the motivation of the employees. Anh (2017) has confirmed that corporate culture governs the feelings and thoughts of employees, so if the corporate culture is taken care of, it may help employees improve their motivation and become more engaged. The study suggests hypothesis H5: Corporate culture positively influences the work motivation of Otuksa Japan's employees. 


\subsection{The relationship between leadership style and motivation}

Managers usually apply one of three leadership styles: directive style (authoritarian), democratic style (collective), and liberal style (laissez-faire or anarchic), cording to Uyen (2007). As confirmed by Chew (2004) shows that employees' motivation depends on the leadership behavior of managers. Inheriting the previous study, Herzberg (2003) had proven that leadership style has a positive impact on motivation. Hence, the study proposes H6: Leadership style positively affects the work motivation of employees at Otuksa Japan.

\subsection{The relationship between workplace relationships with motivation}

All employees in any position, need the support and help of colleagues, seek comfort and friendliness when working (Hill et al., 2014). Besides, employees with good and close relationships with colleagues are more motivated to work and easily achieve organizational goals (Kovach, 1987; Herzberg, 2003). Employees maintain a close relationship and usually share with colleagues, they are more inspired at work (Anh, 2017). The study hypothesized H7: Colleague relationships have a positive effect on the work motivation of employees at Otuksa Japan.

\subsection{The relationship between work motivation and performance}

According to Kovach (1987), worker motivation is a crucial factor to improve work results. Labor productivity is enhanced through motivational policies, which has been demonstrated in previous studies by Herzberg (2003), Kamery (2004), Borman (2004). As argued by Mai Anh (2011) and Anh (2017), there is a positive relationship between work motivation and work results. Therefore, the study proposes H8: Work motivation has a positive impact on the performance of employees at Otuksa Japan.

From the above arguments and hypotheses, the study proposes a model to analyze the influence of work motivation on the performance of employees at Otuksa Japan below.

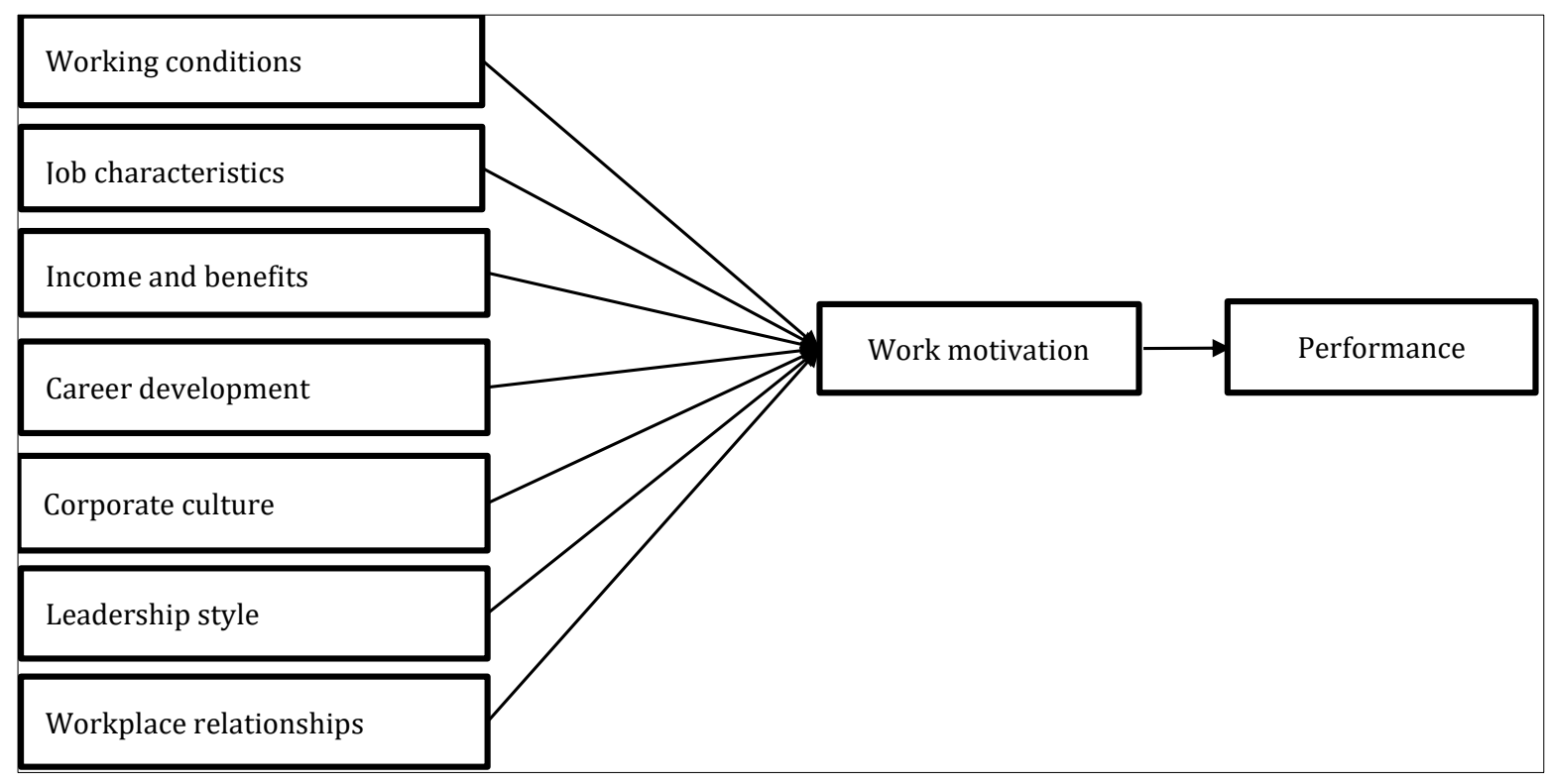

Figure 1 Proposed research model

Table 1 Interpretation of observed variables in the research model

\begin{tabular}{|c|c|c|c|c|}
\hline Factor & Observed variables & Sign & Scale & Reference resources \\
\hline \multirow{4}{*}{$\begin{array}{l}\text { Working } \\
\text { conditions }\end{array}$} & There is necessary and convenient equipment. & W01 & \multirow{4}{*}{$\begin{array}{c}\text { Likert } \\
1-5\end{array}$} & \multirow{4}{*}{$\begin{array}{l}\text { Herzberg (2003), Reio and } \\
\text { Callahon (2004), Robbins } \\
\text { and Judge (2014), Anh } \\
(2017)\end{array}$} \\
\hline & $\begin{array}{l}\text { The working environment ensures the health of } \\
\text { employees. }\end{array}$ & W02 & & \\
\hline & $\begin{array}{l}\text { Feeling comfortable in the current working } \\
\text { space. }\end{array}$ & W03 & & \\
\hline & Working time is reasonable. & W04 & & \\
\hline
\end{tabular}




\begin{tabular}{|c|c|c|c|c|}
\hline Factor & Observed variables & Sign & Scale & Reference resources \\
\hline \multirow{4}{*}{$\begin{array}{c}\text { Job } \\
\text { characteristics }\end{array}$} & The job always requires improvement & $\mathrm{JC} 1$ & \multirow{4}{*}{$\begin{array}{l}\text { Likert } \\
1-5\end{array}$} & \multirow{4}{*}{$\begin{array}{l}\text { Kamery (2004), Hadi and } \\
\text { Adil (2010), Anh (2017) }\end{array}$} \\
\hline & Be proactive in performing the job. & JC2 & & \\
\hline & $\begin{array}{l}\text { The job helps to learn useful skills for career } \\
\text { development. }\end{array}$ & JC3 & & \\
\hline & $\begin{array}{l}\text { Be encouraged to participate in work-related } \\
\text { decisions }\end{array}$ & $\mathrm{JC} 4$ & & \\
\hline \multirow{4}{*}{$\begin{array}{l}\text { Income and } \\
\text { benefits }\end{array}$} & $\begin{array}{l}\text { The salary is commensurate with the employees' } \\
\text { efforts. }\end{array}$ & IB1 & \multirow{4}{*}{$\begin{array}{l}\text { Likert } \\
1-5\end{array}$} & \multirow{4}{*}{$\begin{array}{l}\text { Osterloh et al. (2002), } \\
\text { Herberg (2003), Reio and } \\
\text { Callahon (2004), Anh } \\
(2017)\end{array}$} \\
\hline & $\begin{array}{l}\text { Salary and bonus policies ensure daily-life } \\
\text { expenses for employees and their families. }\end{array}$ & IB2 & & \\
\hline & The company pays on time. & IB3 & & \\
\hline & $\begin{array}{l}\text { A reasonable welfare policy that meets } \\
\text { employees' expectations. }\end{array}$ & IB4 & & \\
\hline \multirow{4}{*}{$\begin{array}{c}\text { Career } \\
\text { development }\end{array}$} & $\begin{array}{l}\text { Participate in career development training } \\
\text { programs. }\end{array}$ & CD1 & \multirow{4}{*}{$\begin{array}{l}\text { Likert } \\
1-5\end{array}$} & \multirow{4}{*}{$\begin{array}{l}\text { Reio and Callahon (2004), } \\
\text { Robbins and Judge (2014), } \\
\text { Anh (2017) }\end{array}$} \\
\hline & $\begin{array}{l}\text { The training programs help to develop personal } \\
\text { capacity. }\end{array}$ & $\mathrm{CD} 2$ & & \\
\hline & $\begin{array}{l}\text { The company creates conditions for employees to } \\
\text { improve their working skills. }\end{array}$ & CD3 & & \\
\hline & $\begin{array}{l}\text { The company offers promotion opportunities for } \\
\text { employees. }\end{array}$ & $\mathrm{CD} 4$ & & \\
\hline \multirow{4}{*}{$\begin{array}{l}\text { Corporate } \\
\text { culture }\end{array}$} & All employees are treated with respect. & $\mathrm{CC} 1$ & \multirow{4}{*}{$\begin{array}{c}\text { Likert } \\
1-5\end{array}$} & \multirow{4}{*}{$\begin{array}{l}\text { Chew (2004), Shah et al. } \\
\text { (2012), Anh (2017) }\end{array}$} \\
\hline & The company's cultures are appropriate. & $\mathrm{CC} 2$ & & \\
\hline & Love the interactive working environment. & $\mathrm{CC} 3$ & & \\
\hline & $\begin{array}{l}\text { Customers and partners highly appreciate the } \\
\text { company's culture. }\end{array}$ & $\mathrm{CC} 4$ & & \\
\hline \multirow{4}{*}{$\begin{array}{l}\text { Leadership } \\
\text { style }\end{array}$} & $\begin{array}{l}\text { Employees receive enthusiastic help from the } \\
\text { leader. }\end{array}$ & LS1 & \multirow{4}{*}{$\begin{array}{c}\text { Likert } \\
1-5\end{array}$} & \multirow{4}{*}{$\begin{array}{l}\text { Chew (2004), Thu and } \\
\text { Khoi (2014), Anh (2017) }\end{array}$} \\
\hline & The leader directly instructs the tasks. & LS2 & & \\
\hline & $\begin{array}{l}\text { The leader motivates employees to improve } \\
\text { performance. }\end{array}$ & LS3 & & \\
\hline & $\begin{array}{l}\text { The leader records achievements and criticizes } \\
\text { politely. }\end{array}$ & LS4 & & \\
\hline \multirow{3}{*}{$\begin{array}{l}\text { Workplace } \\
\text { relationship }\end{array}$} & Reliable and honest colleagues. & WR1 & \multirow{3}{*}{$\begin{array}{c}\text { Likert } \\
1-5\end{array}$} & \multirow{3}{*}{$\begin{array}{l}\text { Hill et al., 2014, Herzberg } \\
\text { (2003), Anh (2017) }\end{array}$} \\
\hline & $\begin{array}{l}\text { Colleagues share experiences and help each other } \\
\text { in work and life. }\end{array}$ & WR2 & & \\
\hline & Colleagues are enthusiastic about teamwork & WR3 & & \\
\hline \multirow{3}{*}{$\begin{array}{l}\text { Work } \\
\text { motivation }\end{array}$} & $\begin{array}{l}\text { Willing to sacrifice self-interest to achieve good } \\
\text { results at work. }\end{array}$ & WM1 & \multirow{3}{*}{$\begin{array}{c}\text { Likert } \\
1-5\end{array}$} & \multirow{3}{*}{$\begin{array}{l}\text { Kovach (1987), Mai Anh } \\
\text { (2011), Thu and Khoi } \\
\text { (2014) }\end{array}$} \\
\hline & Feeling excited about my current job. & WM2 & & \\
\hline & $\begin{array}{l}\text { Always enthusiastic and excited to contribute to } \\
\text { the company's goals. }\end{array}$ & WM3 & & \\
\hline
\end{tabular}




\begin{tabular}{|c|c|c|c|c|}
\hline Factor & Observed variables & Sign & Scale & Reference resources \\
\hline & My working mood is usually good and optimistic. & WM4 & & \\
\hline \multirow{4}{*}{$\begin{array}{l}\text { Job } \\
\text { performance }\end{array}$} & Always complete the assigned tasks. & JP1 & \multirow{4}{*}{$\begin{array}{l}\text { Likert } \\
1-5\end{array}$} & \multirow{4}{*}{$\begin{array}{l}\text { Borman (2004), Robbins } \\
\text { and Judge (2014), Mai } \\
\text { Anh (2011) }\end{array}$} \\
\hline & $\begin{array}{l}\text { Always improve working methods to achieve } \\
\text { better results. }\end{array}$ & JP2 & & \\
\hline & Be proud of my performance. & JP3 & & \\
\hline & The leader highly evaluates my work results. & JP4 & & \\
\hline
\end{tabular}

\subsection{Analytical methods}

To test the research hypotheses, analytical methods used include testing the reliability of the scale by Cronbach's Alpha coefficient, exploratory factor analysis (EFA) to evaluate convergent and discriminant validity, confirmatory factor analysis (CFA) to assess the suitability of data with the market, and structural equation modeling (SEM) to evaluate the impact level of factors on motivation, and the relationship between work motivation and performance at Otuksa Japan.

\subsection{Data collection method}

To apply the SEM model and meet the reliability requirements, the sample size must be from 100 to 200 (Hoyle, 1995). Researchers argued that SEM requires a large sample size because it is based on large sample distribution theory (Raykov and Widaman, 1995). However, the exact size of the sample size is currently not defined. Also, Hoelter (1983) has believed that the minimum sample size should be 200. This study collected 200 observations using convenience sampling. The survey subjects are employees who are working at Otuksa Japan. Therefore, the sample size meets the requirements, ensuring the reliability to test the model.

\section{Results and discussion}

\subsection{Test the reliability of scales}

To determine the factors affecting work motivation and the relationship between work motivation and performance, the study used the software SPSS 22 and AMOS 22 to support the analysis. Results are estimated step by step as follows:

\subsubsection{Step 1: Scale reliability test}

The study checks the reliability of the scales by Cronbach's Alpha coefficient. Based on Table 2, all 36 observed variables of 9 factors achieve Cronbach's Alpha values from 0.743 to 0.832 (Nunnally, 1978; Peterson, 1994; Slater, 1995). Moreover, all variables have item-total correlation values greater than 0.3 . Therefore, they are used for the next step of exploratory factor analysis.

Table 2 Cronbach's Alpha test result

\begin{tabular}{|l|c|c|c|}
\hline \multicolumn{1}{|c|}{ Scale } & Number of observed variables & Cronbach's Alpha & Min item-total correlation \\
\hline Working conditions & 4 & 0.764 & 0.526 \\
\hline Job characteristics & 4 & 0.800 & 0.587 \\
\hline Income and benefit & 4 & 0.808 & 0.585 \\
\hline Career development & 4 & 0.792 & 0.571 \\
\hline Corporate culture & 4 & 0.780 & 0.554 \\
\hline Leadership style & 4 & 0.780 & 0.603 \\
\hline Workplace relationships & 4 & 0.743 & 0.500 \\
\hline Motivation & 4 & 0.771 & 0.509 \\
\hline Performance & 4 & 0.832 & 0.633 \\
\hline
\end{tabular}




\subsubsection{Step 2: Exploratory Factor Analysis (EFA)}

The research model requires the EFA to be performed twice. The first EFA is for independent scales (working conditions, job characteristics, income and benefits, career development, corporate culture, leadership style, and workplace relationships): (1) Reliability of observed variables (Factor loading) $>0.5$; (2) Suitability test of the model $(0.5<$ KMO = $0.740<1.0$ ); (3) Bartlett's test on the correlation of observed variables (Sig. $=0.00<0.05$ ); (4) Total variance extracted $=50.7 \%>50 \%$. The variables achieve discriminant and convergent validity (Hair et al, 1998). Therefore, 7 factors are created from 28 observed variables, there is no variable disturbance, so the name of the factor is still the same. Similarly, the second EFA applies for the motivation and performance scales: (1) Reliability of observed variables (Factor loading) $>0.5$; (2) Suitability of the model $(0.5<\mathrm{KMO}=0.802<1.0)$; (3) Bartlett's test on correlation of observed variables (Sig. $=0.00<0.05$ ); (4) Total variance extracted $=51.05 \%>50 \%$. The observed variables get discriminant and convergent validity (Hair et al, 1998). Thus, these scales do not have disturbance in variables, the factors' name remains.

\subsubsection{Step 3: Confirmatory Factor Analysis (CFA)}

After the EFA, the above nine factors continued to be included in CFA. The results of CFA analysis show that the following conditions are guaranteed: Chi-square/df $=1.092<2$ with $\mathrm{P}=0.000 \leq 0.05$. The TLI and CFI indexes have values of 0.975 and 0.978 , all higher than 0.9. RMSEA $=0.022<0.08$. This proves that the model fits the market data (Gerbing and Anderson, 1988). The standardized regression weights are all $>0.5$ and the unstandardized regression weights are statistically significant, so the scales gain convergent validity. Besides, correlation coefficients among factors are all less than 1 with a standard deviation $(<0.05)$. Therefore, the scales achieve discriminant validity.

Based on the analysis of the composite reliability (Pc) and average variance extracted (Pvc), the Pc meets the conditions while the Pvc of one scale is a bit low $(<0.5)$. However, the Pvc can be accepted at a value from 0.4 or above if the Pc value is greater than 0.6 (Fornell and Larcker, 1981; Fraering and Minor, 2006). Therefore, all the scales in the model meet the requirements of value and reliability, so they are suitable for use in SEM.

Table 3 Scale reliability test result

\begin{tabular}{|l|c|c|c|}
\hline \multicolumn{1}{|c|}{ Factor } & $\begin{array}{c}\text { Number of } \\
\text { observed variables }\end{array}$ & $\begin{array}{c}\text { Composite } \\
\text { Reliability } \mathbf{P}_{\mathbf{c}}\end{array}$ & $\begin{array}{c}\text { Average Variance } \\
\text { Extracted } \mathbf{P}_{\mathbf{v c}}\end{array}$ \\
\hline Working conditions & 4 & 0.77 & 0.45 \\
\hline Job characteristics & 4 & 0.80 & 0.50 \\
\hline Income and benefits & 4 & 0.81 & 0.51 \\
\hline Corporate culture & 4 & 0.79 & 0.49 \\
\hline Career development & 4 & 0.79 & 0.49 \\
\hline Workplace relationships & 3 & 0.75 & 0.51 \\
\hline Leadership style & 4 & 0.78 & 0.47 \\
\hline Work motivation & 4 & 0.83 & 0.51 \\
\hline Job performance & 4 & 0.83 & 0.55 \\
\hline
\end{tabular}

\subsection{Test the theoretical model and research hypothesis}

Following the CFA step, structural equation modeling (SEM) helps to test the research hypotheses.

Table 4 Estimate the relationships in the SEM model

\begin{tabular}{|c|c|c|c|c|c|c|}
\hline Relationship & $\begin{array}{c}\text { Estimated } \\
\text { value }\end{array}$ & $\begin{array}{c}\text { Standard } \\
\text { Error (S.E) }\end{array}$ & $\begin{array}{l}\text { Critical Ratio } \\
\text { (C.R) }\end{array}$ & $\begin{array}{c}\text { Standardized } \\
\text { estimated value }\end{array}$ & $\begin{array}{c}\text { P- } \\
\text { value }\end{array}$ & Hypothesis \\
\hline WM <--- WO & 0.394 & 0.111 & 3.546 & 0.297 & $* * *$ & $\mathrm{H} 1$ \\
\hline WM <--- JC & -0.021 & 0.074 & -0.284 & -0.019 & 0.777 & $\mathrm{H} 2$ \\
\hline
\end{tabular}




\begin{tabular}{|c|c|c|c|c|c|c|c|c|}
\hline WM & $<---$ & IB & 0.495 & 0.121 & 4.096 & 0.346 & $* * *$ & H3 \\
\hline WM & $<---$ & CD & 0.405 & 0.093 & 4.35 & 0.353 & $* * *$ & $\mathrm{H} 4$ \\
\hline WM & $<---$ & $\mathrm{CC}$ & -0.024 & 0.058 & -0.421 & -0.029 & 0.674 & H5 \\
\hline WM & $<---$ & LS & 0.118 & 0.074 & 1.59 & 0.126 & 0.112 & H6 \\
\hline WM & $<---$ & WR & 0.144 & 0.07 & 2.036 & 0.145 & 0.042 & $\mathrm{H} 7$ \\
\hline JP & $<---$ & WM & 0.363 & 0.097 & 3.762 & 0.325 & $* * *$ & H8 \\
\hline
\end{tabular}

The estimated value indicates the degree of impact of each factor on the employees' motivation and performance. The larger the absolute value of this indicator, the higher the impact level. Table 4 shows that the factors of working conditions, income and benefits, career development, and co-worker relations have a positive impact on the motivation of Otuksa Japan's employees. Also, the employees' work motivation positively affects their performance. If work motivation is enhanced, employees work in excitement, joy, and enthusiasm, so work results improve. This research result is consistent with previous studies of Herzberg (2003), Kamery (2004), Borman (2004), Mai Anh (2011), and Anh (2017).

\section{Conclusion}

The study has found out factors that positively affect the work motivation of employees at Otuksa Japan, including working conditions, income and benefits, career development, and workplace relationships. In which, career development is the factor that has the most influence on motivation. Most importantly, the study has indicated a positive relationship between work motivation and performance. Research results are an important scientific basis for managers of Otuksa Japan to have strategies to improve work motivation and work results of employees.

\section{Compliance with ethical standards}

\section{Acknowledgments}

The researchers appreciated all the corrections suggested and recommended by the experts.

\section{Disclosure of conflict of interest}

The authors declare that there are no competing or potential conflicts of interest.

\section{References}

[1] Anh TT. The relationship between motivation and employee performance. Evidence from Ho Chi Minh City green product companies. Ho Chi Minh City Open University Journal of Science. 2017; 58(1): 41- 52.

[2] Bedeian AG. Management (3rd ed.). New York: Dryden Press. 1993.

[3] Borman WC. The concept of organizational citizenship. Current directions in psychological science. 2004; 13(6): 238-241.

[4] Bretz RD, Milkovich GT, Read W. The Current State of Performance Appraisal Research and Practice: Concerns, Directions, and Implications. Journal of Management. 1992; 18(2): 321-352.

[5] Carr GG. Investigating the motivation of retail managers at a retail organization in the Western Cape (Doctoral dissertation, University of the Western Cape). 2005.

[6] CCL. The influence of human resource management practices on the retention of core employees of Australian organizations: An empirical study (Doctoral dissertation, Murdoch University). 2004.

[7] Dung TK, Vy NNL. Employee motivation scale. Economic Development Magazine. 2011; 244: 55-61.

[8] Fornell C, Larcker DF. Evaluating structural equation models with unobservable variables and measurement error. Journal of marketing research. 1981; 18(1): 39-50. 
[9] Fraering M, Minor MS. Sense of community: an exploratory study of US consumers of financial services. International Journal of Bank Marketing. 2006; 24(5): 284-306.

[10] Gerbing DW, Anderson JC. An updated paradigm for scale development incorporating unidimensionality and its assessment. Journal of marketing research. 1988; 25(2): 186-192.

[11] Hadi R, Adil A. Job Characteristics as Predictors of Work Motivation and Job Satisfaction of Bank Employees. Journal of the Indian Academy of Applied Psychology. 2010; 36(2): 294-299.

[12] Hair JF, Tatham RL, Anderson RE, Black W. Multivariate Data Analysis (5th ed.). New Jersey: Prentice-Hall, Inc. 1988.

[13] Herzberg F. The Motivation to Work. New York: Wiley. 1959.

[14] Herzberg F. One more time: How do you motivate employees? (Vol. 65). Boston, MA: Harvard Business Review. 1968.

[15] Herzberg F. One More Time: How Do You Motivate Employees? Harvard Business Review. 2003.

[16] Herzberg F. The motivation-hygiene theory. Organizational behavior one: Essential theories of motivation and leadership, eds JB Miner, ME Sharpe Inc, New York. 2005; 61-74.

[17] Hill CW, Jones GR, Schilling MA. Strategic management: Theory \& cases: An integrated approach. Cengage Learning. 2014.

[18] Hoelter JW. The analysis of covariance structures: Goodness-of-fit indices. Sociological Methods \& Research. 1983; 11(3): 325-344.

[19] Hoyle RH. The structural equation modeling approach: Basic concepts and fundamental issues. In R. H. Hoyle (Ed.), Structural equation modeling: Concepts, issues, and applications. Sage Publications, Inc. 1995; 1-15.

[20] Jankingthong K, Rurkkhum S. Factors affecting job performance: a review of the literature. Humanities, Arts Social Sciences Studies. 2012; 12: 115-127.

[21] Judge TA, Bono JE. Relationship of core self-evaluations traits-self-esteem, generalized self-efficacy, locus of control, and emotional stability-with job satisfaction and job performance: A meta-analysis. Journal of Applied Psychology. 2001; 86(1): 80-92.

[22] Kamery RH. Employee motivation as it relates to effectiveness, efficiency, productivity, and performance. In Proceedings of the Academy of Legal, Ethical and Regulatory. 2004; 8(2): 139-144.

[23] Karunanithy K, Ponnampalam A. A study on the effect of stress on the performance of employees in Commercial Bank of Ceylon in the Eastern Province. European Journal of Business and Management. 2013; 5(27): 87-95.

[24] Kovach KA. What motivates employees? Workers and supervisors give different answers. Business Horizons. 1987; 30(5): 58-65.

[25] Kuvaas B. Performance appraisal satisfaction and employee outcomes: mediating and moderating roles of work motivation. The International Journal of Human Resource Management. 2006; 17(3): 504-522.

[26] Mai Anh. The effect of work motivation on labor efficiency in state-owned companies in Vietnam. Science research. Vietnam National University, Hanoi: International School. 2011.

[27] Nunnally JC. Psychometric Theory. New York: McGraw-Hill Book. 1978.

[28] Nunnally JC, Bernstein IH. Psychometric theory (3rd ed.). New York, NY: McGraw-Hill, Inc. 1994.

[29] Osterloh M, Frost J, Frey BS. The dynamics of motivation in new organizational forms. International Journal of the Economics of Business. 2002; 9(1): 61-77.

[30] Peterson RA. A meta-analysis of Cronbach's coefficient alpha. Journal of consumer research. 1994; 21(2): 381391.

[31] Pinder CC. Work Motivation in Organizational Behavior. London: Psychology Press. 2014.

[32] Raykov T, Widaman KF. Issues in applied structural equation modeling research. Structural Equation Modeling: A Multidisciplinary Journal. 1995; 2(4): 289-318.

[33] Reio TG, Callahan JL. Affect, curiosity, and socialization-related learning: A path analysis of antecedents to job performance. Journal of Business and Psychology. 2004; 19(1): 3-22. 
[34] Robbins SP, Judge TA. Essentials of Organizational Behavior (16th ed.). United Kingdom: Pearson. 2014.

[35] Robbins SP, Judge TA. Organizational behavior (15th ed.). New Jersey: Pearson Education. 2013.

[36] Shah SMA, Jatoi MM, Memon MS. The impact of organizational culture on the employees' job satisfaction \& organizational commitment: A study of faculty members of private sector universities of Pakistan. Interdisciplinary Journal of Contemporary Research in Business. 2012; 3(11): 830-846.

[37] Slater SF. Issues in conducting marketing strategy research. Journal of Strategic Marketing. 1995; 3(4): 257-270.

[38] Thu BTM, Khoi LND. The study of the work motivation of direct production employees in erection corporation Vietnam. Can Tho University Journal of Science. 2014; 35: 66-78.

[39] Uyen VT. Motivation for worker management in State-owned enterprises in Hanoi until 2020. Economics Ph.D. Thesis. Hanoi University. 2007. 